Makale Geliş | Received : 23.01.2019

Makale Kabul | Accepted : 08.04.2019

\title{
Pygmalion (1912) and Ghosts (1881): A Collocational Analysis ${ }^{1}$
}

\section{Pygmalion (1912) and Hortlaklar (1881): Eşdizimsel BirAnaliz \\ ÖMER ŞEKERCI**MÜJDE DEMIRAY**}

\author{
*Ömer ŞEKERCİ, Süleyman Demirel Üniversitesi, Fen-Edebiyat Fakültesi, Batı Dilleri ve Edebiyatı Bölümü, \\ 32260, ISPARTA \\ **Müjde Demiray, Ardahan Üniversitesi, İnsani Bilimler Fakültesi, Mütercim Tercümanlık Bölümü, 75000 \\ ARDAHAN \\ ORCID Numarası | ORCID Number: 0000-0001-9074-3841 / 0000-0002-5370-0049
}

\begin{abstract}
George Bernard Shaw (1856-1950) and Henrik Ibsen (1828-1906) were the most important figures in Modern European Drama in the late nineteenth century. While Ibsen is regarded as the founding father of modern drama in Europe, Shaw is considered to be one of the most important founding figures of the English drama. They both contributed a lot to the development of modern drama in their times. Shaw is known to have been greatly inspired by Ibsen. Shaw's Pygmalion (1912) and Ibsen's Ghosts (1881) are considered to be great dramas of their time, even today, in terms of topics they have dealt with. Our literature survey has shown that plays or drama texts have hardly been analysed collocationally, so we have tried to interpret and read these two major works by the major playwrights from a collocational perspective. The study aims to find out the similarities and differences of collocational style between two playwrights. The plays, in hand, have been read, analysed and interpreted according to the five lexical types of collocations by using simple arithmetic calculation. The lexical collocations have shown us how Shaw and Ibsen treated collocations in Pygmalion and Ghosts, respectively.
\end{abstract}

Keywords: Shaw, Ibsen, Collocations, Pygmalion, Ghosts, Style

\section{ÖZ}

George Bernard Shaw (1856-1950) ve Henrik Ibsen (1828-1906) Modern Avrupa Tiyatrosu'nun on dokuzuncu yüzyıldaki en önemli figürleriydi. Ibsen, Modern Avrupa Tiyatrosu'nun kurucu babası kabul edilirken, Shaw. Modern İngiliz Tiyatrosu'nun en önemli kurucu babalarından birisi olarak bilinir. Her iki oyun yazarı da modern tiyatronun gelişimine büyük katkılar vermişlerdir. Shaw'ın, Ibsen’nin oyunlarından büyük ölçüde esinlendiği bilinmektedir. Shaw'ın Pygmalion ve Ibsen'in Hortlaklar oyunu, ele aldıkları konu bakımından kendi dönemlerinin ve hatta günümüzde sosyal gerçekçi drama türü olarak en önemli eserleri olarak kabul edilmektedirler. Konuyla ilgili edebiyat araştırmamızda tiyatro eserlerinin eşzidimsel olarak nadiren ele alındığını gördük, bu bağlamda bu çalışmada bahsi geçen iki tiyatro eserini, eşdizimsel perspektiften okumaya ve yorumlamaya çalıștık. Bu çalıșma, her iki oyun yazarının eşdizimsel biçemlerindeki benzerliklerini ve farklılıklarını ortaya çıkarmayı amaçlamaktadır. Bahsi geçen bu iki oyun, beş türdeki sözcükse eşdizimlere göre analiz edildi ve yorumlandı. Oyunlardaki sözcüksel eşdizimler basit matematiksel aritmetik yöntem kullanılarak analiz edilmiştir. Sözcüksel eşdizimlerin analizleri ve okunmaları Shaw ve Ibsen'in bu oyunlarında eşdizimleri nasıl ele aldıkları incelenmiştir.

Anahtar Kelimeler: Shaw, Ibsen, Eşdizimler, Pygmalion, Hortlaklar, Biçem.

\footnotetext{
${ }^{1}$ This article has been partly produced from MA thesis titled: “A Collocational Reading of Pygmalion and Ghosts" Suleyman Demirel University, The Institute of Social Sciences, 2018.
} 


\subsection{Introduction}

Theatre has always mirrored life and crossed all boundaries throughout its long history. The nineteenth and twentieth centuries have been one of most exciting and pivotal periods in Western drama. It is known that those periods have produced a great variety of plays than previous periods in terms of thematic scope and stylistics (Innes 1992: 1). The playwrights have always been concerned with issues directly or indirectly experienced by the public in which they live. It is known that literary texts such as novels, poems and plays are analysed textually, thematically and structurally but they are hardly analysed collocationally which is an important part of stylistics.

George Bernard Shaw (1856-1950) and Henrik Ibsen (1828-1906) were the most important figures in modern drama during the nineteenth and twentieth centuries. While Ibsen is regarded as the founding father of Modern Drama in Europe, Shaw is known as one of the most important founding fathers of the English drama. They both contributed a lot to the development of modern drama in their times. Their significance and landmark left on modern drama has still been felt in modern drama texts.

In this study, we intend to analyse Pygmalion by Shaw and Ghosts by Ibsen to find out the style used by Shaw and Ibsen in those plays, as the former has been significantly inspired by the latter's drama, and shed light on to what extent the style of Shaw and Ibsen is similar to or different from each other. Our literature survey on those two plays has shown that the plays have not been analysed from a collocational perspective yet.

\subsection{Definition of Collocations}

It is worthdefining the collocations before we further our study. Collocation is broadly defined as "a natural combination of words; it refers to the way English words are closely associated with each other" (O' Dell \& McCarthy 2008: 4). Furthermore, collocations can be defined as bringing or connecting together two or more words in a language in natural and meaningful way. Sinclair (1991) defines collocations as "occurrence of two or more words within a short space of each other in a text" (170). For instance, we say 'heavy rain', 'strong wind' 'blonde hair', 'pay attention', and 'commit crime'

Collocations are broadly divided into two categories: grammatical and lexical. Our study deals with the lexical collocation in two plays. Collocations are regarded in the scope of stylistics. We have preferred lexical collocations rather than grammatical collocations. It is known that lexical collocations are commonly used by writers in their works as they colour their works. Seven types of lexical collocations have been exploited in our study. They are as following: noun + noun, verb + adjective + noun, verb + noun, adverb + adjective, verb + adverb, adverb + verb and adjective + noun.

Collocations are present in English and they run through the whole English. "No piece of natural spoken or written English is totally free of collocation. For the student, choosing the right collocation will make his speech and writing sound much more natural, more native-speaker-like, even basic intelligibility does not seem to be at issue" (Lea (ed.) 2002: vii). In English language, we know, most single words which are especially common ones embrace a wide range of meanings, some quite different and some that shade into each other by their certain degrees. As it is true, meaning, more specifically precise meaning, in any context, is determined by that context itself. 


\subsection{Classifications of Collocations}

Collocations are classified in many ways by scholars; we will explore how those scholars define them. O' Dell and McCarthy (2008) broadly categorize them as: strong, fixed and weak collocations.

(1) A strong collocation means in which the words are closely connected and associated with each other. For example, mitigating circumstances or factors. His sentence was reduced because of mitigating circumstances. (8)

(2) Fixed collocations are so strong that they cannot be changed or altered in any way. For instance, we can say she was walking to and fro. It means she was walking in one direction and then in the opposite direction (O’ Dell \& McCarthy 2008: 8).

(3) Weak Collocations are those collocations which can be associated with a wide rangeof other words. For example, a broad smile, a broad avenue, and broad shoulders (8).

We have excluded the grammatical collocations as they are not in the scope of our study, so it is worth mentioning and enlarging on lexical collocations.

\subsection{Lexical Collocations}

We should state that lexical collocations do not contain prepositions, infinitives and clauses as opposed to the grammatical collocations. We know that typical collocations consist of nouns, adjectives, verbs, and adverbs (Ilson (ed.) 2010: xxxi). There are lots of collocations in English which consist of a verb and noun, such as bring in an acquittal.

Lexical Collocations 1: Most lexical collocations consist of a verb denoting creating or activation as in the following examples. Come to an agreement, set a record, reach a verdict, set an alarm clock, fly an aircraft, launch a missile.

Lexical Collocations 2: These types are generally made up of a verb meaning eradication or nullification or making void. Here are typical examples of it: reject an offer, reject an appeal, break a code, demolish a house, renege on a promise, ease tension, override a vote, annul a marriage, squander a fortune, withdraw and offer, suspend martial law, denounce a treaty (Ilson (ed..) 2010: xxxii).

Lexical Collocations 3: They consist of an adjective and a noun. Here are one well known pair of examples: strong tea (not mighty tea), weak tea (not a feeble tea), warm regards, kind regards, best regards, crushing defeat, a formidable challenge, a chronic alcoholic, a sweeping generalization.

Lexical Collocations 4: This category consists of a noun and verb. The verb means an action characteristic of the person or thing designated by the noun. For example, alarms go off, bees buzz, blizzards rage, blood circulates, bombs explode, lions roar, cooks cook, bakers bake, dancers dance, fencers fence (Ilson (ed.) 2010: xxxiii).

Lexical Collocations 5: This type indicates what unit is associated with a noun. These types of collocations may exhibit the large unit to which a single member belongs to: For example, a colony of bees, a herd of buffalo, a pack of dogs, etc. Moreover, they may indicate a specific, concrete, small unit of something larger. For instance, a bit/piece of word/advice, an article of clothing, an act of violence,(Ilson (ed..) 2010: xxx1v).

Lexical Collocations 6: This category consists of an adverb and an adjective. Here are examples, deeply absorbed, strictly accurate, hopelessly addicted, sound asleep, keenly aware.

Lexical Collocations 7: They consist of a verb and an adverb. For example, affect deeply, amuse thoroughly, anchor firmly, apologize humbly. 
In addition to the above classifications O'Dell and McCarthy (2008) divides them into topics as given as:

People: Friendship, youth and age, celebrities and heroes, criticizing people, references, appearance and personality: lifelong friends, platonic relationship, child prodigy, go through midlife crisis, senior moment. (O’Dell \& McCarthy 2008: 2).

The Modern World: regulation and authority, the environment, town and country life, personal finance, the economy, social issues, science and technology, health and medicine, criminal justice, war and peace: grant permission, faceless bureaucrats, damp waste, offset carbon emissions, rural idly, urban regeneration, clear one's debts, agree credit limit, curb inflation, antisocial behaviour, dysfunctional family, cutting edge technology, adverse reaction, beyond reasonable doubt, deploy troops, collateral damage ( O’Dell \& McCarthy 2008: 2).

Leisure and lifestyle: social life, talking, news, current affairs, festivals and celebrations, advertisements and fashion, traffic and driving, travel and adventure, sport, plans and decisions, film and book reviews: play host to, juicy gossip, declare independence, decline to comment, movable feast, fashion victim, lengthy delays, off the beaten track, keep in shape, keep fit, deciding factor, tentative suggestion, star-studded cast, hold one's attention (O'Dell \& McCarthy 2008: 1).

Work and study: working life, new employment, thoughts and ideas, business reports, customer services, student life, writing essay, assignments and reports: make a living, take up a post, land a new job, menial tasks, widespread belief, bear in mind, hike in prices, fierce competition, kick up a fuss, grounds for complaint, talented child, mature student, confront issues, critical analysis (O'Dell\& McCarthy 2008: 1).

Basic Concepts: time and space, sound, making things easier, difficulty, quantity and size, change: go down in history, waste of space, incessant noise, viable options, take the easy way out, hinder progress, encounter difficulties, finite number, endless supply, unknown quantity, sweeping changes, sudden shift. (O’Dell \& McCarthy 2008: 2).

Functions: stopping and starting, cause and effect, describing groups and amounts, comparing and contrasting, making an effort, social English, discussing issues, negative situations and feelings, positive situations and feelings: close off a street, dispel rumours, provoke an outcry, dire consequences, swarm of bees, stroke of genius, polar opposites, bear little resemblance to, abortive attempt, give it one's best shot, to be brutally honest, take an exception to, suffer at the hands of, derive pleasure from (O'Dell \& McCarthy 2008: 2).

\subsection{Methodology}

In this study we have tried to analyse the plays in hand by applying textual analysis and used basic mathematical arithmetic to calculate the number of collocations used in the plays. The methodology is based upon the following assumptions.

1) the chosen plays are seen as stylistic actions occurring within a particular social contexts and our focus is on the way that the use of collocations is organised to enable us to find out how the playwrights use the collocations as lexical devices;

2) the structure of collocations in plays is a reflection of how they are used to convey the ideas of the playwrights' to their audience;

3) to figure out the similarities and differences between Shaw and Ibsen by analysing the lexical collocations employed in those mentioned plays; 
4) to reveal to what extent the lexical collocations in these plays exhibit Ibsen's and Shaw's treatment of words.

\subsection{Some Notes on Pygmalion and Ghosts}

Pygmalion is a romance in five acts. It was first staged in Vienna and Berlin as Shaw looked for a response from the continental audience who were unprejudiced by London critics (Bradford 1997: 95). It became very successful in Europe. Broadly speaking, it attacks the hollowness of the British middle class. Shaw emphasizes the importance of proper, decent speech, cleanliness, fashionable dress, good manners but they are not regarded as substitutes for a strong character. "The role of Eliza Doolittle was written for the actress Mrs. Patrick Campbell, with whom Shaw had a friendship that began in the early 1890s and ended in 1939 when he wrote his last letter to her" (Bradford 1997: 96).

Shaw highlights his ideas and concerns with individualism and idealism in his works, most particularly in Pygmalion which is an ancient Greek myth theme turns into being a means of social mobility and a clear demonstration of the power of language to transform one in this Shaw's masterpiece, Pygmalion. The origin of the play goes to Ovid's "The Myth of Pygmalion and Galatea" (ca. A.D. 8) (Bradford 1997: 96).

Ghosts is a domestic drama in three acts written by Ibsen in 1881 and was translated by James McFarlane (McFarlane (tran.) 1981: 89). The characters are Mrs. Helene Alving who is widow of late Captain Alving, Osvald Alving, her son, a painter, Pastor Manders, Engstrand, a carpenter, Regina Engstrand, a maid of Mrs. Alving. The setting is Mrs. Alving's country estate in West Norway.

The play, in fact, aims to deal with a desperate wife whose futile attempts and to keep the dead buried in their graves (Johnston 1992: 190). Its major theme is about the relation of the living to dead. It is a family drama. Its subject matter refers to the subject matter of the ancient Greek tragedy (Johnston 1992: 191). Ibsen, somehow, resurrects "the spirit of Greek drama" (Johnston 1992:191). To Ibsen scholars, it is known that Ibsen was influenced and inspired by the Greek tragedies such as Oresteia, the Oedipus Tyrannous, and The Bacchae. Actually, Ghosts attracts our attention to the themes and conflicts of individual, family and society. It questions ethical issues as the ancient Greek tragedians did.

\subsection{Collocational Analysis of Pygmalion and Ghosts}

Some striking examples related to the five lexical collocation categories, extracted from the plays have been given below. The percentages and the numbers represent the ones in the original thesis study. Considering the space limit and to keep the article at a reasonable level, some examples have been pruned away and the most distinctive ones have been prioritized in this study.

\section{GHOSTS ACT I}

VERB + ADJECTIVE + NOUN

take a grave responsibility

guide stumbling steps

attach a certain importance

use filthy language

\section{PYGMALION ACT I}

VERB + ADJECTIVE + NOUN

keep impertinent remarks (to self)

do genuine scientific work

utter depressing, disgusting sounds

In the thesis titled: "A Collocational Reading of Pygmalion and Ghosts from which the article has been 
partly produced (2018)," the number of verb + adj. + noun collocations is 36 in Act I in Ghosts while the number in Pygmalion is 5 but the percentage is 10\% in Ghosts and 6\% per cent in Pygmalion, because each percentage represents its own act and category.

\section{GHOSTS ACT I}

ADVERB + ADJECTIVE

dripping wet

damned careful

horribly tired

awfully lonely

deeply concerned

disastrously selfish

\section{PYGMALION ACT I}

ADVERB + ADJECTIVE

nearly over

While the number of adverb + adjective collocations is 40 in Act I in Ghosts, the number in Pygmalion is 7 but the percentage is $11 \%$ in Ghosts and $8 \%$ per cent in Pygmalion.

\section{GHOSTS ACT I}

VERB + ADVERB

admit (quite)frankly

examine closely

help considerably

calculate carefully

\section{PYGMALION ACT I}

VERB + ADVERB

Thank (you)kindly

cease instantly

stay (any)longer

While the number of verb + adverb collocations is 23 in Act I in Ghosts, the number in Pygmalion is 6 but the percentages are both $7 \%$, respectively.

\section{GHOSTS ACT I}

ADVERB + VERB

Sorely/ desperately need

seriously believe

distinctly remember

\section{PYGMALION ACT I}

ADVERB + VERB

simply get soaked

The number of adverb + verb collocations is 27 in Act I in Ghosts, whereas the number in Pygmalion is 2 but the percentage is $8 \%$ in Ghosts and 2\% per cent in Pygmalion.

\section{GHOSTS ACT I}

\section{ADJECTIVE + NOUN}

a guiding hand

profligate ways

lawful husband

\section{PYGMALION ACT I}

ADJECTIVE + NOUN

a respectable girl

a blooming busybody

sudden rain 
a run-away wife

glorious free life

a debauched life

youthful indiscretions

blatant immorality articulate speech

commercial millionairesses

While the number of adjective + noun collocations is 126 in Act I in Ghosts, the number in Pygmalion is 33 but the percentage is 33\% in Ghosts and 38\% per cent in Pygmalion in the acts themselves.

\section{GHOSTS ACT II}

VERB + ADJECTIVE + NOUN

get married to a fallen woman

lend a helping hand

have a heart-warming time

show sincere regret

\section{PYGMALION ACT II}

VERB + ADJECTIVE + NOUN

have an interesting accent

pick up free-easy ways

have a good ear and quick tongue

take on a stiff job

The number of verb + adjective + noun collocations is 31 in Act 2 in Ghosts, whereasthe number in Pygmalion is 23 but the percentage is $12 \%$ in Ghosts and $10 \%$ in Pygmalion.

\section{GHOSTS ACT II}

ADVERB + ADJECTIVE

utterly different

closely related

remarkably well developed

radiantly happy

\section{PYGMALION ACT II}

ADVERB + ADJECTIVE

deliciously low

horribly dirty

damned silly

While the number of adverb + adjective collocations is 29 in Act 2 in Ghosts, the number in Pygmalion is 28 but the percentage is $11 \%$ in Ghosts and 13\% in Pygmalion.

\section{GHOSTS ACT II}

VERB + ADVERB

judge too harshly

marry properly

throw wantonly, thoughtlessly
PYGMALION ACT II

VERB + ADVERB

express clearly

dress beautifully

speak properly

While the number of verb + adverb collocations is 18 in Act 2 in Ghosts, the number in Pygmalion is 21 but the percentage is 8\% in Ghosts and 9\% in Pygmalion. 
GHOSTS ACT II

ADVERB + VERB

distinctly remember

honestly believe

half hope
PYGMALION ACT II

ADVERB + VERB

properly say

nearly choke

The number of Adverb +Verb collocations is 11 in Act 2 in Ghosts, the number in Pygmalion is 4 but the percentage is 5\% in Ghosts and 1\% in Pygmalion.

\section{GHOSTS ACT II}

ADJECTIVE + NOUN

miserable affair

a hopeless wreck

fatherly eye

pitiful defeat

old defunct theories
PYGMALION ACT II

ADJECTIVE + NOUN

a fearful strain

a confirmed old bachelor

presumptuous flower girls

draggletailed guttersnipe

a damned nuisance

While the number of adjective + noun collocations is 89 in Act 2 in Ghosts, the number in Pygmalion is 79 but the percentage is 36\% in Ghosts and 35\% in Pygmalion.

\section{GHOSTS ACT III}

VERB + ADJECTIVE + NOUN

give careful consideration

believe in old superstition

suffer unspeakable terror

\section{PYGMALION ACT III}

VERB + ADJECTIVE + NOUN

play with a live doll

tackle the hardest job

fill up the deepest gulf

tackle the most absorbing experiment

find light employment

The number of verb + adjective + noun collocations is 17 in Act 3 in Ghosts, whereas the number in Pygmalion is 19 and the percentage is 14\% in Ghosts and 15\% in Pygmalion.

\section{GHOSTS ACT III}

ADVERB + ADJECTIVE

utterly incomprehensible

dreadfully, pitifully afraid

marvellously light-hearted

\section{PYGMALION ACT III}

ADVERB + ADJECTIVE

awfully funny

frightfully interesting

perfectly cracked

jolly glad 
While the number of adverb + adjective collocations is 15 in Act 3 in Ghosts, the number in Pygmalion is 23 but the percentage is $12 \%$ in Ghosts and $17 \%$ in Pygmalion.

\section{GHOSTS ACT III}

VERB + ADVERB

sit quite calmly

talk quite quietly

\author{
PYGMALION ACT III \\ VERB + ADVERB \\ play quite beautifully \\ speak properly \\ take very seriously
}

The number of verb + adverb collocations is 11 in Act 3 in Ghosts, the number in Pygmalion is 9 but the percentage is $9 \%$ in Ghosts and 7\% in Pygmalion.

\section{GHOSTS ACT III}

ADVERB + VERB

necessarily prove

honestly(not) remember

quite distinctly see

\section{PYGMALION ACT III}

ADVERB + VERB

thoughtfully send

positively reek

half solve

surely believe

While the number of adverb + verb collocations is 8 in Act 3 in Ghosts, the number in Pygmalion is 9 but the percentage is $7 \%$ in Ghosts and $7 \%$ in Pygmalion.

\section{GHOSTS ACT III}

ADJECTIVE + NOUN

spiteful accusations

brilliant sunshine

empty words

poor, tormented mind

\section{PYGMALION ACT III}

ADJECTIVE + NOUN

shallow depression

early Victorian prudery

delicious remarks

large talk

The number of adjective + noun collocations is 41 in Act 3 in Ghosts, whereas the number in Pygmalion is 38 but the percentage is $32 \%$ in Ghosts and 30\% in Pygmalion.

\section{FINDINGS}

We have tried to figure out and analyse how Ibsen deals with the lexical collocations in Ghosts and how Shaw treats the lexical collocations and their use in Pygmalion from a collocational perspective. The plays have been divided into five lexical collocational categories to demonstrate the similarities and the differences between them: (1) "verb + adjective + noun", (2) "adverb + adjective", (3) "verb + adverb", (4) "adverb + verb" and (5) "adjective + noun" lexical collocations have been prioritized in the article to demonstrate how the playwrights coloured their plays in terms of their distinctive style and preferences by using those lexical collocations.

What we have seen is that the "verb + adjective + noun" category in Ghost is slightly higher than in Pygmalion when considered the acts in themselves. The category of "adjective + noun" ranks first 
throughout both plays in percentage. Both dramatists apparently prefer describing the nouns to portray accurate images and to elicit certain emotions in addressing to the audience or readers. The percentage of adverb + adjective and verb + adverb categories in both plays are almost at equal rate. Adverb + verb category is the rarest exploited type of collocations explored by Ibsen and Shaw.

\section{CONCLUSION}

The collocational analyses and interpretations of both plays have shown that, though Shaw was greatly inspired by Ibsen's social realist dramas, the style of both playwrights differ from each other in some respects in terms their use of collocations. Our analysis has demonstrated that both plays are rich in terms of collocations which colour the style of both playwrights. This study has also illustrated that, though both playwrights mainly wrote social realist plays, Ibsen and Shaw mainly differ in picking and using collocations to colour their language to give the message of their characters to the audience. It has been observed that both playwrights aptly use collocations, mainly strong collocations. This study will open new horizons for the future researchers to interpret drama texts from different perspectives. This study has just touched some aspects of collocations and their usage in drama texts. Teaching of collocations and their use may be an effective vehicle to make students expose to drama texts.

\section{REFERENCES}

Bradford, R. (1997). Stylistics. The New Critical Idiom. London and New York: Routledge.

Ilson, R. (ed.) (2010). The BBI Combinatory Dictionary for English. Your Guide to Collocations and Grammar. Third edition. Amsterdam / Philadelphia: John Benjamin's Publishing Company.

Innes, C. (1992). Modern British Drama 1890-1990. Cambridge: Cambridge University Press.

Johnston, B. (1992). The Ibsen Cycle. Pennsylvania: Pennsylvania University Press.

Lea, D. (ed.) (2002). Oxford Collocations Dictionary for Students of English. Oxford: Oxford University Press.

McFarlane, J. (tran.) (1981). World's Classics Henrik Ibsen Four Major Plays, Oxford: Oxford University Press.

O’Dell, F. \& McCarthy, M. (2008). English Collocations in Use Advanced. Cambridge: Cambridge University Press.

Sinclair, J. (1991). Corpus, Concordance, Collocation. Oxford: Oxford University Press. 